Jurnal Cendekia Akuntansi

Volume 1, Nomor 2

Kediri, Desember 2020

\title{
PENGARUH RASIO PROFITABILITAS DAN RASIO SOLVABILITAS TERHADAP RETURN SAHAM PADA PERUSAHAAN MANUFAKTUR SUB SEKTOR MAKANAN DAN MINUMAN YANG TERDAFTAR DI BEI PERIODE 2014- 2017
}

\author{
Neni Latifatur Rokhmah ${ }^{1}$ \\ Agus Athori ${ }^{2}$ \\ ${ }^{1,2}$ Universitas Islam Kadiri \\ Email: agusathori@uniska-kediri.ac.id
}

\begin{abstract}
ABSTRAK
Penelitian ini bertujuan untuk mengetahui pengaruh rasio profitabilitas dan rasio solvabilitas terhadap return saham pada perusahaan manufaktur sub sektor makanan dan minuman yang terdaftar di BEI periode 2014-2017. Variabel independen yang digunakan dalam penelitian ini adalah profitabilitas dan solvabilitas. Variabel dependen yang digunakan dalam penelitian ini adalah return saham. Penelitian ini menggunakan data sekunder dengan jumlah sampel 11 perusahaan. Analisis data digunakan dengan regresi linier berganda dengan bantuan SPSS'16 dan juga menggunakan teknik purposive sampling.

Hasil penelitian menunjukkan bahwa variabel profitabilitas dengan indikator EPS dan ROA berpengaruh terhadap return saham, indikator ROE tidak berpengaruh terhadap return saham. Variabel solvabilitas dengan indikator DAR tidak berpengaruh terhadap return saham, indikator DER berpengaruh terhadap return saham. Secara simultan semua indikator profitabilitas dan solvabilitas berpengaruh terhadap return saham.

Kemampuan prediksi dari 5 indikator terhadap return saham diperoleh $\mathrm{R}$ Square sebesar 0,697 atau 69,7\% dapat disimpulkan bahwa indakator EPS, ROA, ROE, DAR, DER mampu mempengaruhi return saham sebesar 69,7\% dan sisanya $30,3 \%$ dipengaruhi oleh indikator lain diluar penelitian.
\end{abstract}

Kata Kunci: EPS, ROA, ROE, DAR, DER, dan ReturnSaham

\section{ABSTRACT}

This study aims to determine the effect of profitability ratios and solvency ratios on stock returns in the food and beverage sub-sector manufacturing 
companies listed on the Indonesia Stock Exchange for the period 2014-2017. The independent variable used in this study is profitability and solvency. The dependent variable used in this study is stock returns. This study uses secondary data with a total sample of 11 companies. Data analysis was used with multiple linear regression with the help of SPSS16 and also using purposive sampling technique.

The results showed that profitability variables with EPS and ROA indicators affect stock returns, the ROE indicator does not affect stock returns. Solvability variables with the DAR indicator have no effect on stock returns, DER indicators affect stock returns. Simultaneously all indicators of profitability and solvency affect stock returns.

Predictive ability of 5 indicators for stock returns obtained by $R$ Square of 0.697 or $69.7 \%$ can be concluded that the indicator of EPS, ROA, ROE, DAR, DER is able to influence stock returns by $69.7 \%$ and the remaining $30.3 \%$ is influenced by other indicators outside of research.

Keywords: EPS, ROA, ROE, DAR, DER, and Stock Return

\section{PENDAHULUAN}

\section{Latar Belakang Masalah}

Analisis laporan keuangan merupakan salah satu cara untuk mengetahui kinerja perusahaan suatu periode (Kasmir, 2010:66). Laporan keuangan sendiri pada dasarnya terdiri dari neraca, laporan laba rugi, laporan perubahan modal, laporan arus kas, dan laporan atas laporan keuangan. Dengan adanya laporan keuangan para pemimpin dapat melihat jelas mengenai kondisi perusahaaan. Tanpa adanya laporan keuangan, perusahaan akan kesulitan menganalisis apa yang terjadi dalam perusahaan mereka, bagaimana kondisi dan posisi perusahaannya. Selain untuk kepentingan internal perusahaan, laporan keuangan juga dapat di akses oleh pihak eksternal seperti investor, terutama perusahaan yang sudah go public. Publikasi laporan keuangan perusahaan adalah saat yang di tunggu investor sehingga investor juga dapat mengetahui perkembangan perusahaan, bagaimana return saham, bagaimana kondisinya, yang mana digunakan sebagai pertimbangan untuk membeli dan menjual sahamnya.

Hasil analisis laporan keuangan juga akan memberikan informasi tentang kelemahan dan kekuatan yang dimiliki perusahaan. Dengan mengetahui kelemahan, maka manajemen akan dapat memperbaiki atau menutupi kelemahan tersebut. Kekuatan yang dimiliki perusahaan harus dipertahankan atau bahkan ditinggalkan, kekuatan ini dapat dijadikan modal perusahaan. Yang jelas dengan adanya kelemahan dan kekuatan yang dimiliki, maka akan terlihat kinerja perusahaan. Dalam melakukan analisis laporan keuangan didasarkan pada laporan keuangan perusahaan yang dapat dianalisis melalui rasio keuangan.

Rasio keuangan merupakan indeks yang menghubungkan dua angka akuntansi dan diperoleh dengan membagi satu angka dengan lainnya. Rasio keuangan digunakan untuk mengevaluasi kondisi keuangan dan kinerja perusahaan. Hasil rasio keuangan ini akan kelihatan kondisi kesehatan perusahaan yang bersangkutan. Hasil rasio keuangan inilah yang digunakan untuk menilai kinerja dalam suatu periode apakah mencapai target. Disamping itu untuk 
menilai kemampuan dalam memberdayakan sumber daya perusahaan secara efektif dan efisien. Terdapat beberapa rasio keuangan yang dapat digunakan untuk mengukur kinerja perusahaan yaitu: rasio likuiditas, rasio aktivitas, rasio profitabilitas, rasio solvabilitas, dan rasio pasar.

Rasio profitabilitas merupakan rasio yang mana perusahaan masing-masing pengukuran dihubungkan dengan volume penjualan, total aktifa dan modal sendiri (Syamsudin, 2011:59). Rasio profitabilitas terdiri dari 6 rasio yaitu : Gross Profit Margin (GPM), Net Profit Margin (NPM), Return on Asset (ROA), Return on Equity (ROE), Operating Return on Asset (OPRA), Operating Ratio (OPR).

Rasio solvabilitas merupakan rasio yang digunakan untuk mengukur sejauh mana aktiva perusahaan dibiayai dengan utang. Artinya, berapa besar beban utang yang ditangguhkan perusahaan dibandingkan dengan aktivanya. Dalam arti luas dikatakan bahwa rasio solvabilitas digunkan untuk mengukur kemampuan perusahaan untuk mmbayar seluruh kewajiban baik jangka pendek maupun jangka panjang apabila perusahaan dibubarkan.

Earning Per Share (EPS) merupakan rasio untuk mengukur keberhasilan manajemen dalam mencapai keuntungan bagi pemegang saham. Rasio yang rendah berarti manajemen belum berhasil untuk memuaskan pemegang saham, sebaliknya dengan rasio yang tinggi, maka kesejahteraan pemegang saham meningkat dengan pengertian lain bahwa tingkat pengembalian tinggi, sehingga mempengaruhi return saham.

Return On Assets (ROA) disebut dengan Tingkat Pengembalian Aset yang menunjukan persentase keuntungan (laba bersih) yang diperoleh perusahaan sehubungan dengan keseluruhan sumber daya atau rata-rata jumlah aset. Dengan kata lain, Return on Assets adalah rasio yang mengukur seberapa efisien suatu perusahaan dalam mengelola asetnya untuk menghasilkan laba selama suatu periode dan dinyatakan dalam presentase. Tujuan perusahaan adalah menghasilkan pendapatan dan tentunya juga menghasilkan keuntungan atau laba bagi perusahaan itu sendiri. Rasio ini dapat membantu manajemen dan investor untuk melihat seberapa baik suatu perusahaan mampu mengembalikan return pada perusahaan. Semakin baik kinerja perusahaan maka harga saham semakin tinggi sehingga return saham juga semakin tinggi.Return On Equity (ROE) merupakan suatu pengukuran dari penghasilan yang tersedia bagi para pemilik perusahaan atas modal yang mereka investasikan di dalam perusahaan. Rasio ini diperoleh dengan membagi laba setelah pajak dengan rata-rata modal sendiri. Sama halnya dengan ROA semakin baik kinerja perusahaan akan semakin tinggi harga saham sehingga semakin meningkat return saham sehingga ROE memungkin kan berpengaruh positif terhadap return saham.

Debt to Asset Ratio (DAR)adalah rasio yang mengukur berapa besar aktiva perusahaan yang dibiayai oleh kreditur. Semakin tinggi debt to asset ratio maka semakin besar jumlah modal pinjaman yang digunakan didalam menghasilkan keuntungan bagi perusahaan. Debt to Equity Ratio (DER) merupakan rasio yang digunakan untuk menilai utang dengan ekuitas. Untuk mencari rasio ini dengan cara membandingkan antara seluruh utang, termasuk utang lancar dan seluruh equitas. Rasio ini digunakan untuk mengetahui jumlah dana yang disediakan peminjam (kreditor) dengan pemilik perusahaan jika laba per saham meningkat maka akan berdampak pada meningkatnya harga saham atau return saham, sehingga secara teori DER akan berpengaruh positif terhadap return saham. 
Berdasarkan pernyataan diatas maka masih ditemukan permasalahan yang menghubungkan pendekatan keuntungan dan solvabilitas terhadap return saham, sehingga perlu dilakukan penelitian lebih lanjut sehingga peneliti melakukan penelitian dengan judul "Pengaruh Rasio Profitabilitas dan Rasio Solvabilitas terhadap Return Saham pada Perusahaan Manufaktur Sub Sektor Makanan dan Minuman yang ada di Bursa Efek Indonesia".

\section{Batasan Penelitian}

Adapun batasan dalam penelitian ini adalah :

pokok permasalahan yang akan diteliti dan dibahas mencapai sasaran yang diinginkan, maka batasan dalam penelitian ini adalah rasio profitabilitas dengan menggunakan rumus earning per share, return on asset, return on equity, dan rasio solvabilitasdengan menggunakan debt to asset ratio, debt to equity ratio. Penelitian berlaku pada perusahaan manufaktur sub sektor makanan dan minuman yang terdaftar di Bursa Efek Indonesia periode 2014-2017.

\section{Perumusan Masalah}

Berdasarkan latar belakang tersebut, maka rumusan masalah yang dibentuk sebagai berikut :

1. Bagaimana pengaruh rasio profitabilasterhadap return saham pada perusahaan manufaktur sub sektor makanan dan minuman di Bursa Efek Indonesia periode 2014-2017.

2. Bagaimana pengaruh rasio solfabilitas terhadap return saham pada perusahaan manufaktur sub sektor makanan dan minuman di Bursa Efek Indonesia periode 2014-2017.

3. Bagaimana pengaruh rasio profitabilitas dan rasio solvabilitasterhadap return saham pada perusahaan manufaktur sub sektor makanan dan minuman di Bursa Efek Indonesia periode 2014-2017.

\section{Tujuan Penelitian}

Berdasarkan pokok permasalahan tersebut, maka penelitian ini memiliki tujuan sebagai berikut :

1. Untuk mengetahui pengaruh rasio profitabilitasterhadap return saham pada perusahaan manufaktur sub sektor makanan dan minuman di Bursa Efek Indonesia periode 2014-2017.

2. Untuk mengetahui pengaruh rasio solvabilitasterhadap return saham pada perusahaan manufaktur sub sektor makanan dan minuman di Bursa Efek Indonesia periode 2014-2017.

3. Untuk mengetahui pengaruh rasio profitabilitas dan rasio solvabilitas terhadap return saham pada perusahaan manufaktur sub sektor makanan dan minuman di Bursa Efek Indonesia periode 2014-2017.

\section{Manfaat Penelitian}

Berdasarkan rumusan masalah dan tujuan penelitian, maka penelitian ini diharapkan dapat memberikan manfaat sebagai berikut:

\section{a. Manfaat Operasional}

Hasil penelitian ini diharapkan dapat dijadikan pedoman bagi investor untuk memprediksi return saham perusahaan yang ada di Bursa Efek Indonesia, mengetahui kinerja perusahaan, menambah wawasan dan pengetahuan dalam dunia keuangan, membantu pimpinan perusahaan dalam mengambil keputusan.

\section{b. Manfaat Akademik}


Hasil penelitian ini diharapkan dapat di jadikan sebagai bahan referensi untuk penelitian berikutnya, menambah wawasan ilmu ekonomi yang berkaitan dengan analisis rasio keuangan berupa rasio profitabilitas dan rasio solvabilitas.

\section{LANDASAN TEORI}

\section{Analisis Fundamental}

Menurut (Subramanyam dan Wild, 2010:11) menegaskan bahwa analisis fundamental merupakan proses menentukan nilai perusahaan dengan menganalisis dan menginterpretasikan faktor-faktor kunci untuk ekonomi, industri, dan perusahaan. Bagi para investor yang melakukan analisis fundamental, informasi laporan keuangan merupakan salah satu jenis informasi yang paling mudah dan paling murah didapatkan dibanding alternatif informasi lainnya.

\section{Rasio Profitabilitas}

Menurut (Kasmir, 2010:115), rasio profitabilitas merupakan rasio untuk mengukur efektivitas manajemen secara keseluruhan yang ditunjukkan oleh besar kecilnya tingkat keuntungan yang diperoleh dalam hubungannya dengan penjualan maupun investasi. Semakin baik rasio profitabilitas maka semakin baik menggambarkan kemampuan tingginya perolehan keuntungan perusahaan.

\section{Earning per share}

Menurut (Prastowo, 2011:89),Earning per share adalah jumlah laba yang menjadi hak untuk setiap pemegang satu lembar saham biasa Tergantung dari struktur modal perusahaan.

\section{Return on asset}

Menurut(Kasmir, 2010:115), menjelaskan bahwa Return On Asset adalah rasio yang menunjukan hasil (return) atas jumlah aktiva yang digunakan dalam perusahaan. Dengan kata lain Return On Asset (ROA) dapat didefinisikan sebagai rasio yang menunjukkan seberapa banyak laba bersih yang bisa diperoleh dari seluruh kekayaan yang dimiliki perusahaan.

\section{Return on equity}

Menurut (Mardiyanto, 2009:196), ROE adalah rasio yang digunakan untuk mengukur keberhasilan perusahaan dalam menghasilkan laba bagi para pemegang saham.

\section{Rasio Solvabilitas}

Menurut (Harahap, 2011:306)Rasio leverage menggambarkan hubungan antara hubungan perusahaan terhadap modal maupun asset. Rasio ini dapat melihat seberapa jauh perusahaan dibiayai oleh utang atau pihak luar dengan kemampuan perusahaan yang digambarkan oleh modal (equity).

\section{Debt to Asset Ratio}

Menurut (Syamsuddin, 2011:54),debt to asset ratio merupakan rasio yang mengukur berapa besar aktiva perusahaan yang dibiayai oleh kreditur.

\section{Debt to Equity Ratio}

Menurut (Fahmi, 2014:75),Debt to Equity Ratio merupakan kemampuan perusahaan dalam menggambarkan perbandingan hutang dan ekuitas dalam pendanaan perusahaan dan menunjukkan kemampuan modal sendiri perusahaan terebut untuk memenuhi seluruh kewajibannya. 


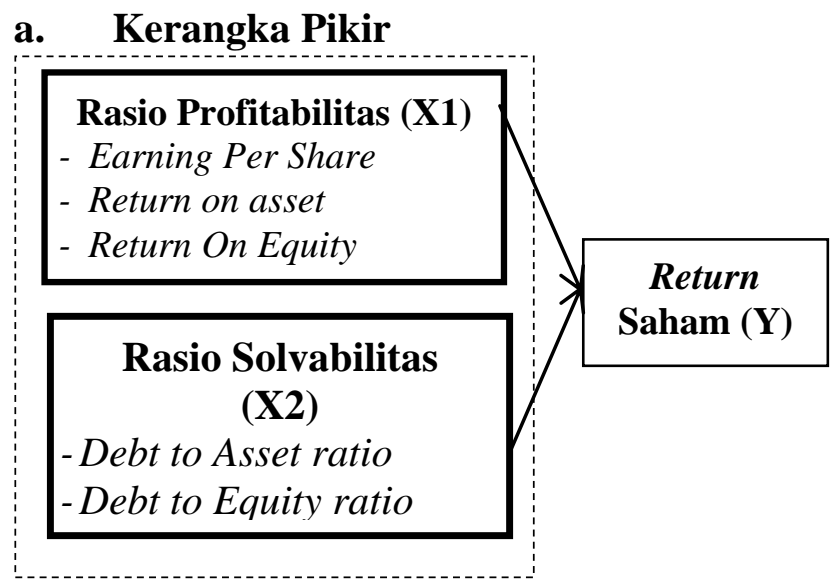

\section{METODE PENELITIAN}

\section{Ruang Lingkup Penelitian}

Dalam penelitian ini peneliti memilih Bursa Efek Indonesia (BEI) sebagai tempat untuk melakukan riset.

\section{Lokasi Penelitian}

Penelitian ini dilakukan di Galeri Investasi Syariah Bursa Efek Indonesia di Universitas Islam Kadiri yang beralamatkan di Jalan Sersan Suharmaji No. 38, Manisrenggo, Kota Kediri, Jawa Timur karena berbagai informasi yang dapat menunjang hasil penelitian dapat diperoleh di lokasi tersebut dengan menggunakan data sekunder. Alasan dipilihnya lokasi ini adalah karena letaknya yang hanya berada pada lingkup kampus sehingga memudahkan dalam mendapatkan informasi dan pengambilan data laporan keuangan yang dibutuhkan.

\section{Populasi dan Sampel}

\section{1) Populasi}

Populasi dalam penelitian ini adalah perusahaan manufaktur sub sektor makanan dan minuman yang terdaftar di Bursa Efek Indonesia (BEI) pada periode 2014 sampai 2017. Jumlah populasi dalam penelitian ini adalah 20 perusahaan.

\section{2) Sampel}

a. Dalam penelitian ini cara untuk pengambilan sampel yaitu dengan cara menggunakan metode purposive sampling.Perusahaan manufaktur sub sektor makanan dan minuman yang terdaftar di Bursa Efek Indonesia (BEI) berturut-turut selama periode 2014 sampai dengan 2017.

b. Jumlah perusahaan manufaktur Sub sector makanan dan minuman yang terdaftar di BEI berturut-turut selama periode penelitian, yaitu 2014 sampai dengan 2017.

c. Perusahaan yang mengalami kerugiaan selama periode penelitian, yaitu 2014 sampai dengan 2017.

\section{Teknik Pengumpulan Data}

Data-data yang diperlukan dalam penelitian ini adalah data laporan keuangan perusahaan manufaktur yang terdaftar di Bursa Efek Indonesia (BEI) periode 2014-2017 yang diperoleh dari Indonesia Stock Exchange (IDX). 
Dalam penelitian ini teknik pengumpulan data yang digunakan adalah sebagai berikut:

a. Dokumentasi

b. Studi Pustaka

\section{Identifikasi Variabel Penelitian}

Adapun yang menjadi variabel dalam penelitian ini dapat diidentifikasikan sebagai berikut :

1. Variabel terikat (dependent variable)

Dalam penelitian ini yang menjadi variabel terikat adalah Return saham (Y).

2. Variabel bebas (Independent variable)

a. Rasio profitabilitas (X1)

Yang mana menggunakan rumus Earning Per Share, Return On Assets, Return On Equity

b. Rasio solvabilitas (X2)

Yang mana menggunakan rumus yaitu Debt to Asset Ratio, Debt to Equity Ratio

\section{Definisi Operasional Variabel}

1. Profitabilitas (X1)

Rasio profitabilitas merupakan rasio untuk menilai kemampuan persahaan dalam mencari keuntungan. Rasio ini juga memberikan ukuran tingkat efektifitas menejemen suatu perusahaan.

\section{a Earning Per Share}

Earning per share, merupakan rasio untuk mengukur keberhasilan manajemen dalam mencapai keuntungan bagi pemegang saham tiap lembar saham yang di pegang. Adapun rumus untuk menghitung earning per share adalah :

Earning per share $=\frac{\text { Laba Bersih }}{\text { Jumlah Saham Beredar }}$

\section{b Return On Assets}

Return on asset merupakan rasio antara laba bersih yang berbanding terbalik dengan keseluruhan aktiva untuk menghasilkan laba. Adapun rumus untuk menghitung return on asset adalah :

Return On sset $=\frac{E A T}{\text { Total assets }} \mathrm{X} 100 \%$

\section{c Return On Equity}

Return on equity adalah rasio yang digunakan untuk mengukur keberhasilan perusahaan dalam menghasilkan laba bagi para pemegang saham. Adapun rumus untuk menghitung return on equity adalah :

Return On Equity $=\frac{\text { EAT }}{\text { Total Equity }} \mathrm{X} 100 \%$

\section{Solvabilitas (X2)}

Rasio solvabilitas, merupakan rasio yang digunakan untuk mengukur sejauh mana aktiva perusahaan dibiayai dengan utang. Artinya, berapa besar beban utang yang ditangguhkan perusahaan dibandingkan dengan aktivanya.

\section{a. Debt to Asset Ratio}


Debt to asset ratio merupakan rasio yang mengukur berapa besar aktiva perusahaan yang dibiayai oleh kreditur. Semakin tinggi debt to asset ratio maka semakin besar jumlah modal pinjaman yang digunakan didalam menghasilkan keuntungan bagi perusahaan. Adapun rumus untuk menghitung Debt to asset ratio adalah :

Debt to Asset Ratio $=\frac{\text { total debt }}{\text { Total assets }}$

\section{b. Debt to Equity Ratio}

Debt to Equity Ratio merupakan rasio yang digunakan untuk menilai utang dengan ekuitas. Untuk mencari rasio ini dengan cara membandingkan antara seluruh utang, termasuk utang lancar dengan seluruh ekuitas. Adapun rumus untuk menghitung debt to equity ratio adalah :

Debt to equity ratio $=\frac{\text { total debt }}{\text { Equitas }}$

3. Return Saham (Y)

Return saham merupakan kelebihan harga jual saham diatas harga belinya. Semakin tinggi harga jual saham diatas harga belinya, makase makin tinggi pula return yang diperoleh investor. Adapun rumus untuk menghitung return sahamadalah :

$$
\text { Return Saham }=\frac{P t-P t^{-1}}{P t^{-1}}
$$

\subsection{Teknik Analisis Data}

Penelitian ini menggunakan teknik analisis data regresi linier berganda, yang digunakan untuk mengetahui hubungan antara Indikator dependen yaitu return saham dengan variable independen yaitu earning per share, return on asset return on equity, debt to asset ratio, debt to equity ratio. Penelitian menggunakan alat uji statistik dengan mengggunakan program SPSS yang terdiri dari statistik deskriptif, uji asumsi klasik dan uji hipotesis.

\section{HASIL PENELITIAN DAN PEMBAHASAN}

\section{Hasil Analisis Regresi Linear Berganda}

\begin{tabular}{|c|c|c|c|c|c|c|}
\hline \multicolumn{7}{|c|}{ Coefficientsa } \\
\hline \multirow{2}{*}{\multicolumn{2}{|c|}{ Model }} & \multicolumn{2}{|c|}{$\begin{array}{c}\text { Unstandardized } \\
\text { Coefficients }\end{array}$} & \multirow{2}{*}{$\begin{array}{c}\text { Standardized } \\
\text { Coefficients } \\
\text { Beta } \\
\end{array}$} & \multirow[b]{2}{*}{$\mathrm{T}$} & \multirow[b]{2}{*}{ Sig. } \\
\hline & & B & Std. Error & & & \\
\hline & (Constant) & 1.637 & 1.990 & & .823 & .000 \\
\hline & Earning Per Share & -.383 & .213 & -.466 & -1.801 & .009 \\
\hline & Return On Asset & -5.991 & 4.097 & -3.599 & -1.462 & .016 \\
\hline & Return On Equity & 6.206 & 4.060 & 3.780 & 1.529 & .420 \\
\hline & Debt to Asset Ratio & 4.574 & 7.633 & 1.058 & .599 & .556 \\
\hline & Debt to Equity Ratio & -4.504 & 5.514 & -1.754 & -.817 & .042 \\
\hline
\end{tabular}


Uji asumsi klasik telah dilakukan dengan hasil semua kriteria terpenuhi sehingga bisa dilanjutkan untuk regresi linier berganda. Berikut ini adalah perumusan hasil regresi linier berganda.

$\mathrm{Y}=1,637-0,383 \mathrm{EPS}-5,991 \mathrm{ROA}+6,206 \mathrm{ROE}+4,574 \mathrm{DAR}-4,504 \mathrm{DER}$

\section{Hasil Koefisien Determinasi $\left(\mathbf{R}^{2}\right)$}

\begin{tabular}{|l|c|r|r|c|}
\hline \multicolumn{1}{|c|}{ Model Summary $^{\mathbf{b}}$} \\
\hline Model & $\mathrm{R}$ & R Square & $\begin{array}{c}\text { Adjusted R } \\
\text { Square }\end{array}$ & $\begin{array}{c}\text { Std. Error of the } \\
\text { Estimate }\end{array}$ \\
\hline 1 & $.708^{\mathrm{a}}$ & .697 & .521 & .48643 \\
\hline
\end{tabular}

Tabel diatas menunjukkan bahwa nilai korelasi (R) sebesar 0,708 atau $70,8 \%$ artinya hubungan antara variabel independen terhadap variabel dependen dalam kategori kuat dan koefisien determinasi (Adjusted R Square) sebesar 0,521. Hal ini berarti 52,1\% variasi return saham dapat dijelaskan oleh kelima indikator variabel bebas, sedangkan $47,9 \%$ dijelaskan variabel lain yang tidak dikaji dalam penelitian ini.

\section{Pengujian Hipotesis}

a. Pengujian Hipotesis secara parsial (Uji t)

1) Pengujian Hipotesis 1 (Profitabilitas)

Berdasarkan hasil perhitungan pada SPSS diperoleh nilai Variabel Profitabilitas $\left(\mathrm{X}_{1}\right)$ dengan Indikator earning per share adalah 0,009. Hal ini menunjukkan bahwa nilai signifikan uji $\mathrm{t}$ variabel Indikator earning per share $\left(\mathrm{X}_{1}\right) \leq 0,050$ yang berarti $\mathrm{H}_{0}$ ditolak dan $\mathrm{H}_{\mathrm{a}}$ diterima. Hasil dari pengujian parsial ini adalah Profitabilitas $\left(\mathrm{X}_{1}\right)$ dengan indikator earning per share berpengaruh signifikan terhadap return saham.

Berdasarkan hasil perhitungan pada SPSS diperoleh nilai signifikan variabel Profitabilitas $\left(\mathrm{X}_{1}\right)$ dengan return on asset adalah 0,016 . Hal ini menunjukkan bahwa nilai signifikan uji t variabel $\left(\mathrm{X}_{1}\right)$ dengan Indikator return on asset $\leq 0,050$ yang berarti $\mathrm{H}_{0}$ ditolak dan $\mathrm{H}_{\mathrm{a}}$ diterima. Hasil dari pengujian parsial ini adalah variabel $\left(\mathrm{X}_{1}\right)$ dengan indikator return on asset berpengaruh signifikan terhadap return saham.

Berdasarkan hasil perhitungan pada SPSSdiperoleh nilai signifikan variabel Profitabilitas $\left(X_{1}\right)$ dengan indikator return on equity adalah 0,420 . Hal ini menunjukkan bahwa nilai signifikan uji t variabel Profitabilitas $\left(\mathrm{X}_{1}\right)$ dengan Indikator return on equity $>0,050$ yang berarti $\mathrm{H}_{0}$ diterima dan $\mathrm{H}_{\mathrm{a}}$ ditolak. Hasil dari pengujian parsial ini adalah Profitabilitas $\left(\mathrm{X}_{1}\right)$ dengan Indikator return on equity tidak berpengaruh signifikan terhadap return saham.

2) Pengujian Hipotesis 2(Solvabilitas)

Berdasarkan hasil perhitungan pada SPSSdiperoleh nilai signifikan variabel Solvabilitas $\left(\mathrm{X}_{2}\right)$ dengan Indikator debt to asset ratio adalah 0,556. Hal ini menunjukkan bahwa nilai signifikan uji t variabel variabel Solvabilitas $\left(\mathrm{X}_{2}\right)$ dengan Indikator debt to asset ratio $>0,050$ yang berarti $\mathrm{H}_{0}$ diterima dan $\mathrm{H}_{\mathrm{a}}$ 
ditolak. Hasil dari pengujian parsial ini adalah variabel Solvabilitas $\left(\mathrm{X}_{2}\right)$ dengan Indikator debt to asset ratio tidak berpengaruh signifikan terhadap return saham.

Berdasarkan hasil perhitungan pada SPSS diperoleh nilai signifikan Solvabilitas $\left(\mathrm{X}_{2}\right)$ dengan Indikator debt to equity ratio adalah 0,042 . Hal ini menunjukkan bahwa nilai signifikan uji t Solvabilitas $\left(\mathrm{X}_{2}\right)$ dengan Indikator debt to equity ratio $>0,050$ yang berarti $\mathrm{H}_{0}$ ditolak dan $\mathrm{H}_{\mathrm{a}}$ diterima. Hasil dari pengujian parsial ini adalah Solvabilitas $\left(\mathrm{X}_{2}\right)$ dengan Indikator debt to equity ratio berpengaruh signifikan terhadap return saham (Y).

b. Pengujian Hipotesis secara simultan (Uji F)

ANOVA $^{b}$

\begin{tabular}{|l|r|r|r|r|r|}
\hline Model & Sum of Squares & df & Mean Square & F & Sig. \\
\hline 1 Regression & 2.776 & 5 & .555 & 2.346 & $.008^{\text {a }}$ \\
Residual & 6.175 & 38 & .346 & & \\
Total & 8.951 & 43 & & & \\
\hline
\end{tabular}

Berdasarkan hasil perhitungan pada SPSS diperoleh nilai signifikan adalah 0,008. Hal ini menunjukkan bahwa nilai signifikan uji $\mathrm{F}$ variabel indikator earning per share, return on asset, return on equity, debt to asset ratio dan debt to equity ratio $\leq 0,05$ yang berarti $\mathrm{h}_{0}$ ditolak dan $\mathrm{h}_{\mathrm{a}}$ diterima. Hasil dari pengujian simultan ini adalah earning per share, return on asset, return on equity, debt to asset ratio, dandebt to equity ratio berpengaruh signifikan terhadap return saham.

\section{Pengaruh Rasio profitabilitas terhadap return saham}

Berdasarkan dari hasil perhitungan uji $\mathrm{t}$ antara variabel Profitabilitas dengan Indikator earning per share dengan variabel return sahamvariabel Profitabilitas dengan Indikator earning per share menunjukkan nilai koefisien regresi sebesar $-0,383$ dengan nilai sig. sebesar 0,009 lebih kecil dari 0,050, hal ini berarti Indikator earning per share berpengaruh siginifikan positif terhadap return saham. Sehingga hipotesis yang menyatakan bahwa Indikator earning per share berpengaruh signifikan terhadap return saham dapat diterima atau $\mathrm{Ha}$ diterima dan $\mathrm{H}_{0}$ ditolak yaitu ada pengaruh signifikan antara variabel profitabilitas dengan Indikator earning per share Terhadap return saham.

Earning Per Share (EPS) merupakan rasio untuk mengukur keberhasilan manajemen dalam mencapai keuntungan bagi pemegang saham. Rasio yang rendah berarti manajemen belum berhasil untuk memuaskan pemegang saham, sebaliknya dengan rasio yang tinggi, maka kesejahteraan pemegang saham meningkat dengan pengertian lain bahwa tingkat pengembalian tinggi, sehingga mempengaruhi return saham. Hal ini berarti bahwa semakin tinggi EPS maka semakin tinggi pula return saham yang di bagikan kepada investor pada perusahaan tersebut. Begitupun sebaliknya semakin rendah EPS maka return saham yang dibagikan kepada investor juga semakin rendah. Hasil penelitian ini sesuai dengan penelitian yang dilakukan oleh (Hermawan, 2012). yang mengemukakan bahwa earning per shareberpengaruh signifikan terhadap return saham.

Berdasarkan dari hasil perhitungan uji $\mathrm{t}$ antara variabel profitabilitas dengan indikator return on asset dengan variabel return saham. variabel 
profitabilitas dengan indikator return on asset menunjukkan nilai koefisien regresi sebesar -5,991 dengan nilai sig. Sebesar 0.016 lebih kecil dari 0,050, hal ini berarti indikator return on asset berpengaruh siginifikan positif terhadap return saham. Sehingga hipotesis yang menyatakan bahwa indikator return on asset berpengaruh signifikan terhadap return saham dapat diterima atau ha diterima dan $\mathrm{h}_{0}$ ditolak yaitu ada pengaruh signifikan antara variabel profitabilitas dengan indikator return on asset terhadap return saham. Semakin tinggi rasio ini maka semakin baik produktivitas asset dalam memperoleh keuntungan bersih. Hal ini akan meningkatkan daya tarikperusahaan kepada investor. Peningkatan daya tarik perusahaan menjadikan saham perusahaan tersebut makin diminati investor, karena tingkat pengembalian akan semakin besar. Hal ini juga diduga akan berdampak pada return saham perusahaan tersebut.Hasil penelitian ini sesuai dengan penelitian yang dilakukan oleh (Achmad, 2011) yang mengemukakan bahwa return on asset berpengaruh signifikan terhadap return saham.

Berdasarkan dari hasil perhitungan uji $\mathrm{t}$ antara variabel profitabilitas dengan indikator return on equity dengan variabel return saham. variabel profitabilitas dengan indikator return on equity menunjukkan nilai koefisien regresi sebesar 6.206 dengan nilai sig. Sebesar 0.420 lebih besar dari 0,050, hal ini berarti indikator return on equity tidak berpengaruh siginifikan positif terhadap return saham. Sehingga hipotesis yang menyatakan bahwa indikator return on equity tidak berpengaruh signifikan terhadap return saham dapat diterima atau $\mathrm{h}_{0}$ diterima dan $\mathrm{h}_{\mathrm{a}}$ ditolak yaitu tidak ada pengaruh signifikan antara variabel profitabilitas dengan indikator return on equity terhadap return saham. Hasil ini bertentangan sesuai dengan teori bahwa return on equity merupakan tolak ukur profitabilitas, dimana para pemegang saham pada umumnya ingin mengetahui tingkat probabilitas modal saham dan keuntunganyang telah mereka tanam kembali dalam bentuk laba yang ditanam. Apabila saham perusahaan diperdagangkan di bursa saham, tinggi rendahnya return on equity akan mempengaruhi tingkat permintaan saham tersebut di bursa dan harga jualnya.Hasil penelitian ini sesuai dengan penelitian yang dilakukan oleh (Achmad, 2011) yang mengemukakan bahwa return on equity tidak berpengaruh signifikan terhadap return saham.

Pengaruh Rasio Solvabilitas terhadap return saham

Berdasarkan dari hasil perhitungan uji t antara variabel solvabilitas dengan indikator debt to asset ratio terhadap variabel return sahampada tabel 4.17, variabel solvabilitas dengan indikator debt to asset ratio menunjukkan nilai koefisien regresi sebesar 4.574dengan nilai sig. Sebesar 0.556 lebih besar dari 0,050, hal ini berarti indikator debt to asset ratio tidak berpengaruh siginifikan positif terhadap return saham. Sehingga hipotesis yang menyatakan bahwa indikator debt to asset ratio tidak berpengaruh signifikan terhadap return saham dapat diterima atau $\mathrm{h}_{0}$ diterima dan $\mathrm{h}_{\mathrm{a}}$ ditolak yaitu tidak ada pengaruh signifikan antara variabel profitabilitas dengan indikator debt to asset ratio terhadap return saham. Hal ini mengidentifikasikan bahwa rasio utang yang di bandingankan asset tidak menyebabkan perubahan pada return saham. Hasil penelitian ini sesuai dengan penelitian yang dilakukan oleh (gunawan, dan hardiani, 2014) yang mengemukakan bahwa variabel debt to asset ratio tidak berpengaruh terhadap return saham. 
Berdasarkan dari hasil perhitungan uji t antara variabel solvabilitas dengan indikator debt to equity ratio terhadap variabel return saham. variabel solvabilitas dengan indikator debt to equity ratio menunjukkan nilai koefisien regresi sebesar 4.504 dengan nilai sig. Sebesar 0.042 lebih kecil dari 0,050 , hal ini berarti indikator debt to equity ratio berpengaruh siginifikan terhadap return saham. Sehingga hipotesis yang menyatakan bahwa variabel solvabilitas dengan indikator debt to equity ratio berpengaruh signifikan terhadap return saham dapat diterima atau $h_{a}$ diterima dan $h_{0}$ ditolak yaitu ada pengaruh negatif dan signifikan antara variabel solvabilitas dengan indikator debt to equity ratio terhadap return saham. Hal ini berarti semakin tinggi der pada suatu perusahaan maka berdampak pada semakin rendahnya return saham yang di terima oleh investor pada perusahaan tersebut begitupun sebaliknya. Hasil penelitian ini sesuai dengan penelitian yang dilakukan oleh (Arista, 2012) yang menemukan bahwa debt to equity ratio berpengaruh signifikan terhadap return saham.

\section{Pengaruh Rasio Profitabitas dan Rasio Solvabilitas terhadap Return saham}

Hasil dari pengujian hipotesis yang telah dilakukan, menunjukkan bahwa secara simultan rasio profitabilitas dan rasio solvabilitas dengan indikator EPS, ROA, ROE, DAR dan DER berpengaruh signifikan terhadap return saham. Berdasarkan tabel 4.18 diperoleh nilai signifikan adalah 0,008. Hal ini menunjukkan bahwa nilai signifikan uji $\mathrm{F}$ variabel profitabilitas dan solvabilitas Indikator earning per share, return on asset,return on equity, debt to asset ratio dan debt to equity ratio $\leq 0,05$ yang berarti $\mathrm{H}_{0}$ ditolak dan $\mathrm{H}_{\mathrm{a}}$ diterima. Hasil dari pengujian simultan ini adalah earning per share, return on asset, return on equity, debt to asset ratio, dandebt to equity ratio berpengaruh signifikan terhadap return saham. Dengan menunjukkan nilai korelasi (R) sebesar 0,708 atau 70,8\% artinya hubungan antara variabel independen terhadap variabel dependen dalam kategori kuat dan koefisien determinasi (Adjusted R Square) sebesar 0,521. Hal ini berarti $52,1 \%$ variasi return saham dapat dijelaskan oleh kelima indikator variabel bebas, sedangkan 47,9\% dijelaskan variabel lain yang tidak dikaji dalam penelitian ini.

\section{KESIMPULAN DAN SARAN}

\section{Kesimpulan}

Berdasarkan hasil penelitian yang telah dilakukan untuk mengetahui pengaruh Rasio Profitabilitas dan Rasio Solvabilitas terhadap return sahampada perusahaan manufaktur sub sektor makanan dan minuman yang terdaftar di Bursa Efek Indonesia periode 2014 - 2017, maka kesimpulan yang dapat diambil dalam penelitian ini adalah sebagai berikut :

1. Dari analisis data secara parsial diperoleh hasil bahwa variabel profitabilitas dengan indikator earning per share dengan variabel return sahammenunjukkan nilai koefisien regresi sebesar -0,383 dengan nilai sig. Sebesar 0,009 lebih kecil dari 0,050, hal ini berarti indikator earning per share berpengaruh siginifikan positif terhadap return saham.

Variabel profitabilitas dengan indikator return on asset terhadap variabel return sahammenunjukkan nilai koefisien regresi sebesar $-5,991$ dengan nilai sig. Sebesar 0.016 lebih kecil dari 0,050, hal ini berarti indikator return on asset berpengaruh siginifikan positif terhadap return saham. 
Variabel profitabilitas dengan indikator return on equity terhadap variabel return sahammenunjukkan nilai koefisien regresi sebesar 6.206 dengan nilai sig. Sebesar 0.420 lebih besar dari 0,050 , hal ini berarti indikator return on equity tidak berpengaruh siginifikan positif terhadap return saham.

2. Dari analisis data secara parsial diperoleh hasil bahwa variabel solvabilitas dengan indikator debt to asset ratio terhadap variabel return sahammenunjukkan nilai koefisien regresi sebesar 4.574dengan nilai sig. Sebesar 0.556 lebih besar dari 0,050, hal ini berarti indikator debt to asset ratio tidak berpengaruh siginifikan positif terhadap return saham.

Variabel solvabilitas dengan indikator debt to equity ratio terhadap variabel return sahammenunjukkan nilai koefisien regresi sebesar -4.504 dengan nilai sig. Sebesar 0.042 lebih kecil dari 0,050 , hal ini berarti variabel solvabilitas dengan indikator debt to equity ratio berpengaruh siginifikan terhadap return saham.

3. Dari analisis data secara simultan diperoleh hasil bahwa rasio profitabilitas dan rasio solvabilitas dengan indikator EPS, ROA, ROE, DAR dan DER berpengaruh signifikan terhadap return saham. Diperoleh dari nilai signifikan sebesar 0,008, lebih kecil dari 0,050 $(0,008<0,050)$.

\section{Saran}

Berdasarkan dari hasil penelitian dan kesimpulan diatas, maka saran dalam penelitian ini adalah sebagai berikut:

\section{a. Bagi Calon Investor}

Informasi mengenai kemampuan perusahaan dalam menghasilkan laba sangatlah penting bagi para calon investor yang ingin menanamkan modalnya ke suatu perusahaan, tetapi tidak kalah pentingnya jika para calon investor disamping memperhatikan rasio keuangan yang berhubungan dengan laba seperti yang digunakan dalam penelitian ini yaitu earning per share, return on asset, return on equity, debt to asset ratio, dan debt to equity ratio juga harus memperhatikan kondisi keuangan perusahaan karena return saham belum tentu memberikan laba yang tinggi tetapi juga dapat memberikan kerugian bagi investor.

\section{b. Bagi Pihak Perusahaan}

Perusahaan dapat meyakinkan dan menarik para investor dengan meningkatkan profitabilitasnya. Hal yang dapat dilakukan ialah dengan meningkatkan return on asset, pendapatan per lembar saham, memperbaiki kinerja perusahaan demi mencapai penjualan yang maksimal dan faktor-faktor lain yang mungkin dapat mempengaruhi peningkatan return saham sehingga menjadi lebih baik lagi. Misalnya dalam meningkatkan return on asset perusahaan disarankan mampu meningkatkan penjualan yang ideal sebesar $10 \%$ dengan meminimalisir biaya operasi dari penjualan itu sendiri. Hal ini dapat membantu pihak perusahaan menarik minat investor untuk berinvestasi, agar dapat menunjang keberhasilan perusahaan sehingga akan tetap dapat bersaing dengan perusahaan- perusahaan sejenis atau yang lainnya di masa yang akan datang.

\section{c. Bagi Peneliti Selanjutnya}

Penelitian ini dapat digunakan sebagai dasar penelitian selanjutnya dengan menambah variabel independen dan jumlah perusahaan yang mempengaruhi 
return saham, sehingga dalam penelitian yang baru tersebut lebih mampu menjelaskan variabel yang mempengaruhi return saham.

\section{DAFTAR PUSTAKA}

Bursa Efek Indonesia. Laporan Keuangan Tahunan 2014, 2015,2016, dan 2017. (diakses di http://www.idx.co.id.)

Dwialesi, Juanita Bias dan Ni Putu Ayu, Darmayanti . 2016. "Pengaruh FaktorFaktor Fundamental Terhadap Return Saham Indeks Kompas 100”.EJurnal Manajemen Unud, Vol. 5, No.9

Fahmi, Irham. 2014. Manajemen Keuangan Perusahaan dan Pasar Modal. Edisi Pertama. Jakarta: Mitra Wacana Media.

Harahap, Sofyan syafri. 2011. Analisis Kritis Atas Laporan Keuangan. Cetakan ke-10. Jakarta:PT RajaGrafindo persada.

Hermawan,Dedi Aji. (2012). "Pengaruh Debt To Equity Ratio, Earning Per Share Dan Net Profit Margin Terhadap Return Saham”. Management Analysis Journal, Vol.1,No. 5.

Kasmir. 2010. Pengantar Manajemen Keuangan. Jakarta : Prenadamedia Group.

Mardiyanto, Handoyo, 2009, Intisari Manajemen Keuangan, Hal.196, Jakarta: PT Grasindi

Prastowo, Dwi. 2011. Analisis Laporan Keuangan. Yogyakarta : Sekolah Tinggi Ilmu Manajemen YKPN.

Subramanyam, K.R., and Hohn J. Wild, (2008), Financial Statement Analysis. NewYork: McGraw-Hill, 10th edition. (Diterjemahkan oleh Dewi Yanti, (2010),Analisis Laporan Keuangan. Jakarta: Penerbit Salemba Empat.

Syamsuddin, Lukman.2011. Manajemen Keuangan Perusahaan: konsep aplikasi dalam perencanaan, pengawasan, dan pengambilan keputusan. Jakarta: Rajawali pers. 